\title{
ANALISIS FAKTOR HAMBATAN BISNIS ONLINE TERHADAP PELAKU USAHA PENJUALAN BIBIT IKAN \\ ( Study Kasus di Desa Buden Kec. Deket Kab. Lamongan )
}

\author{
Sabilar Rosyad \\ Prodi Manajemen, Fakultas Ekonomi, Universitas Islam Lamongan \\ Jl. Veteran No.53A Lamongan \\ Telp. ( 0322 ) 324706, Faks. ( 0322 ) 324706 \\ Email:jpim@unisla.ac.id
}

\begin{abstract}
ABSTRAK
Penelitian ini memfokuskan permasalahan pada bagaimana analisis hambatan bisnis online bagi penjual bibit ikan yang ada di desa. buden. Teori yang digunakan dalam penelitian ini adalah Teori Uses and Gratifications. Metode penelitian adalah metode penelitian kualitatif. Informan yang ditetapkan adalah 5 informan. Teknik pengumpulan data yang digunakan dalam penelitian ini adalah wawancara terstruktur secara langsung.hasil penelitian yang ditemukan adalah masalah keterlambatan pengiriman dari supplyer. Solusi : Pembeli menyatakan estimasi waktu pengiriman serta kemungkinan keterlambatan pengiriman.. Masalah barang tidak sesuai ekspektasi pembeli. Solusi: Foto promosi suatu produk, khususnya produk bibit ikan, lebih baik untuk menggunakan jenis ikan, pengemasan, dan pengiriman sebagai foto promosi, karena lebih realistis dibandingkan foto promosi yang tidak menggunakan model. Masalah pengiriman tidak sesuai dengan alamat pembeli. Solusi: Jika seseorang ingin membeli suatu barang secara online, hendaknya ia mempelajari alamat lengkap tujuan pengiriman terlebih dahulu, untuk menghindari kesalahan pengiriman oleh pembeli. Masalah penipuan/barang tidak dikirim. Solusi: Mempelajari kinerja penjual online melalui respon-respon pelanggan yang biasanya tertera di halaman promosi penjual online. Ini juga dapat digunakan oleh penjual bisnis online, untuk menyediakan tempat bagi para pembeli untuk memberi respon yang dapat dibaca secara umum. Karena dengan respon-respon pembeli yang baik, dapat meningkatkan reputasi penjual online hingga lebih terpercaya. Yang menjadi saran atau masukan dalam penelitian ini adalah : penelitian ini masih perlu dilakukan pengembangan, oleh karena itu untuk penelitian mendatang terhadap e- commerce perlu dikaji lebih lanjut mengenai analisis hambatan bisnis online. kemudian untuk masyarakat, Khususnya pelaku usaha penjualan bibit ikan di desa buden, dapat mengkaji hasil penelitian ini sebagai pembelajaran sebelum melakukan bisnis online, baik itu sebagai penjual, reseller, maupun pembeli.
\end{abstract}


Kata Kunci : Analisis, Hambatan, Bisnis Online

\section{PENDAHULUAN}

Kini internet telah menjadi bagian tidak terpisahkan dari masyarakat modern. Bahkan bagi generasi yang lahir setelah tahun 1995, internet telah membentuk sebuah dunia tersendiri seperti layaknya bumi di tempat manusia berada. Dalam dunia maya ini, melalui beraneka ragam peralatan teknologi informasi dan komunikasi, para individu maupun kelompok-kelompok masyarakat saling berinteraksi, bertukar pikiran, dan berkolaborasi untuk melakukan sejumlah aktivitas kehidupan. Di era informasi seperti saat ini internet memegang peranan penting dalam segala aspek kehidupan manusia. Internet menjadi media yang banyak di gunakan oleh kalangan mahasiswa untuk memenuhi kebutuhan informasi guna menunjang kebutuhan study yang mereka tempuh maupun untuk menunjang aktivitas mereka. Hal ini terjadi karena pada dasarnya kebutuhan setiap individu sangatlah beraneka ragam, sehingga adanya kebutuhan inilah yang menimbulkan motif untuk menemukan informasi pada sebuah media yang paling dianggap tepat. Akibatnya muncul berbagai cara dan strategi untuk mendapatkan informasi tersebut. Dalam hal ini internet banyak digunakan karena menawarkan berbagai kemudahan untuk dapat mengakses berbagai literatur dan referensi ilmu pengetahuan yang sesuai dengan kebutuhan para akademisi.Internet dalam era informasi telah menempatkan dirinya sebagai salah satu pusat informasi yang dapat diakses dari berbagai tempat tanpa dibatasi oleh ruang dan waktu. Internet disebut sebagai pusat informasi bebas hambatan karena dapat menghubungkan satu situs informasi ke situs informasi lainnya dalam waktu yang singkat. Internet menjadi pilihan alternatif pencarian informasi bagi mahasiswa selain perpustakaan. Internet menjadi sumber informasi yang mempunyai banyak manfaat dibandingkan dengan sumber informasi lainnya. Saat ini sudah semakin banyak kantor lembaga pemerintah yang memiliki koneksi kedalam jaringan internet. Beberapa diantaranya bahkan telah mempublikasikan lembaganya kedalam bentuk situs homepage pada world wide web (www). Perkembangan internet di indonesia telah menunjukkan perkembangan yang cukup signifikan berdasarkan data dari Asosiasi Penyelenggara Jasa Internet Indonesia (APJII) pada tahun 2016, pengguna internet di Indonesia telah mencapai 132,7 juta jiwa, sedangkan jumlah penduduk Indonesia sendiri pada tahun 2016 diperkirakan berjumlah 256,2 juta jiwa. Hal ini berarti 
lebih dari setengah penduduk Indonesia merupakan pengguna internet.

Sejalan dengan cepatnya

perkembangan bidang teknologi, perusahaan- perusahaan yang termasuk dalam industri kecil, menengah maupun besar, yang merupakan salah satu dari sekian banyak pelaku dan penunjang kegiatan ekonomi di negeri ini, semakin dipacu untuk menggunakan teknologi yang maju sebagai senjata untuk tetap survive dan memenangkan persaingan yang kian hari terasa ketat dan keras. Oleh karena itu, teknologi web di internet memainkan peran yang sangat penting, yaitu memungkinkan organisasi ataun perusahaan memasuki pasar dengan cara yang mudah, murah, dan tanpa batasan geografis, semuanya akan berada dalam apa yang dinamai ruang maya (Cyberspace). Dalam hal ini, organisasi atau perusahaan akan bersaing dengan pelaku bisnis yang lain di dunia maya (virtual world). Akhir-akhir ini penggunaan internet yang mengurus kepada cyberspace, yang akan mendominasi seluruh kegiatan di atas permukaan bumi di masa kini maupun masa datang, yang secara umum akan berubah menjadi alat untuk persaingan antara perusahaan yang satu dengan yang lainnya. Ini pun akan membawa dampak yang sangat besar bagi setiap perusahaan. Dampak pada aspek persaingan adalah terbentuknya tingkat kompetisi yang semakin tajam yang memebuat perusahaan dalam globalisasi ekonomi ini membuat perubahan menjadi konstan, pesat, radikal dan serentak. Sehingga perusahaan harus memiliki kemampuan yang cepat untuk ber adaptasi terhadap perubahan yang terjadi sehingga perusahaan akan mampu bersaing dengan para kompetitinya. Penggunaan teknologi diharapkan dapat memberikan manfaat yang besar terhadap dunia bisnis yang kompetitif tersebut. Perusahaan yang mampu bersaing dalam kompetisi tersebut adalah perusahaan yang mampu mengimplementasikan teknologi ke dalam perusahaannya. Salah satu jenis implementasi teknologi dalam hal meningkatkan persaingan bisnis adalah dengan menggunakan electronic commerce (e-commerce) yaitu untuk memasarkan berbagai macam produk atau jasa, baik dalam bentuk fisik maupun digital. Dengan ini e-commerce didefinisikan sebagai proses pembelian dan penjualan atara dua belah pihak di dalam suatu perusahaan dengan adanya pertukaran barang, jasa, atau informasi melalui media internet. Ternyata tidak mudah dalam mengimplementasikan e-

\section{Jurnal Penelitian Ilmu Manajemen}


commerce dikarenakan banyaknya faktor yang terkait dan teknologi yang harus dikuasi. Dengan demikian ada "tiga kategori dasar atau jenis-jenis e-commerce yaitu Business To Consumer (B2C), Business To Business (B2B) dan Consumer To Consumer(C2C)".

Dengan adanya tiga kategori di atas, dapat memudahkan para pelaku bisnis untuk melakukan sasaran yang akan dituju. Dengan demikian, "yang harus diingat dalam melangsungkan aktivitas bisnis ecommerece yaitu: adanya proses baik penjualan maupun pembelian secara elektronik adanya konsumen atau perusahaan dan adanya jaringan penggunaan komputer secara online untuk melakukan transaksi bisnis". Di samping itu, bisnis e-commerce mempunyai beberapa keuntungan antara lain yaitu: "dapat memperluas jaringan mitra bisnis, jangkauan pemasaran menjadi semakin luas, aman secara fisik, efektif, efisien, dan fleksibel, selain itu terdapat kekurangan dalam bisnis e-commerce ini antara lain: meningkatkan individualisme, terkadang menimbulkan kekecewaan dan tidak manusiawi. Dalam mendapatkan kepercayaan dalam ecommerce, ada beberapa prinsip yang harus dipenuhi, antara lain keterbukaan (business practice disclosure) yaitu akan melakukan transaksi sesuai dengan yang dijanjikan. Integritas transaksi (transaction integrity) yaitu tagihan yang sesuai dengan transaksi. Dan juga perlindungan terhadap informasi (information protection) yaitu penjagaan informasi agar tidak jatuh ke pihak yang tidak berkaitan dengan bisnisnya. Peningkatan transaksi menggunakan ecommerce oleh perusahaan merupakan indikasi bahwa manajemen memiliki komitmen terhadap pemanfaatan cara baru. Atau lebih tepat digambarkan sebagai suatu komitmen untuk memanfaatkan e-commerce di dalam pengembangan perusahaan. Selama ini, sistem penjualan yang digunakan oleh perusahaan hanya bersifat manual dan secara tertulis, yang tidak jarang cenderung menyesatkan. Dengan adanya layanan jasa berupa e-commerce yang dapat secara cepat dapat dinikmati oleh pelanggan maupun perusahaan sendiri, maka segala layanan yang diinginkan oleh para pelanggan dapat segera ditindak lanjuti dengan secepat mungkin, sehingga perusahaan tersebut akan mampu memberikan palayanan yang terbaik dan tercepat bagi para pelanggan. Ecommerce sering menunggangi situs maupun media sosial yang sering dikunjungi konsumen. Sebagai media

\section{Jurnal Penelitian Ilmu Manajemen}


sosial yang paling populer digunakan dikalangan para pelaku usaha saat ini, Facebook, Instagram, Twitter, dan Website sering menjadi jembatan utama dalam transaksi e- commerce. Sebagai salah satu konsumen e-commerce, dalam hal ini penulis mengamati bahwa cukup banyak pelaku usaha yang sering melakukan transaksi e-commerce, baik sebagai penjual, reseller, distributor, maupun konsumen. Berkaitan dengan permasalahan tersebut maka saya sebagai peneliti mencoba mengaitkan permasalahan ini dengan kajian ilmu komunikasi bisnis dimana akan diteliti tentang "Analisis Hambatan Bisnis Online bagi pelaku usaha penjualan bibit ikan ( Study Kasus Di desa Buden ) ". Untuk lebih mengarahkan apa yang akan diteliti dalam penelitian ini diperlukan penetapan rumusan masalah sebagai berikut:

1. Apa saja hambatan yang sering dihadapi oleh penjual dalam bisnis online?

2. Bagaimana cara penjual bisnis online menghadapi hambatan-hambatan tersebut?

3. Apa saja hambatan yang sering dihadapi oleh pembeli dalam bisnis online?

4. Bagaimana cara pembeli bisnis online menghadapi hambatan-hambatan tersebut?

\section{LANDASAN TEORI}

\section{Konsep Komunikasi}

Orang melakukan komunikasi dengan mempergunakan suara, isyarat, tulisan atau lainya, yang secara umum disebut lambang (Symbol, Code). Pada keadaan tertentu dimana komunikasi tidak dapat dilakukan secara langsung, diperlukan adanya perantara atau alat yang disebut sarana/media komunikasi. Istilah komunikasi sudah lazim kita dengarkan, namun didefenisikan secara luas sebagai “berbagi pengalaman”. Jika dilacak dari akar katanya, maka kata komunikasi atau communication dalam bahasa inggris berasal dari kata latin communis yang berarti sama sama communication atau communicare yang berarti membuat sama (to make common). Istilah pertama (communis) adalah istilah yang paling sering disebut sebagai asal usul komunikasi yang merupakan akar dari kata latin lainya yang sama makna. Definisi lain yang sama makna dengan komunikasi adalah komunitas (community) yang juga menekankan kesamaan dan kebersamaan. Kata ini merujuk kepada sekelompok yang berkumpul atau hidup bersama untuk mencapai tujuan tertentu sebagai proses pembagian makna dan sikap. Tentang komunikasi terdapat beberapa defenisi yang dikemukakan oleh para ahli, diantaranya

\section{Jurnal Penelitian Ilmu Manajemen}


sebagai berikut: Banyak alasan mengapa manusia berkomunikasi. Thomas $\mathbf{M}$. Scheidel mengatakan, orang berkomunikasi terutama untuk menyatakan dan mendukung identitas diri, dan untuk mempengaruhi orang lain, untuk merasa, berpikir, atau berperilaku sebagaimana yang diinginkan.Arifin Anwar, tentang pengertian secara etimoogis dari komunikasi adalah:" istilah komunikasi itu sendiri terkandung makna bersama-sama (common, commonnese dalam bahasa Inggris), istilah komuikasi dari bahasa Indonesia dan dalam bahasa Inggris berasal dari bahasa latin, yakni: communication, yang berarti: pemberitahuan, pemberi, pemberi bagian (dalam sesuatu) pertukaran, dimana sipembicara mengharapkan pertimbangan atau jawaban dari pendengarnya, ikut bagian. Kalau kata kerjanya: communicare, artinya berdialog atau bermusyawarah."

Menurut Pratikno, komunikasi merupakan suatu kegiatan usaha manusia untuk menyampaikan apa yang menjadi pemikiran dan perasaanya, harapan ataupun pengalamannya kepada orang lain. Komunikasi merupakan salah satu istilah paling popular dalam kehidupan manusia, sebagai sebuah aktifitas, komunikasi selalu dilakukan manusia. Manusia tidak bias tidak berkomunikasi. Jika manusia normal merupakan mahluk sosial yang selalu membangun interaksi antara sesamanya maka komunikasi adalah merupakan sarana utamanya. Oleh sebab itu komunikasi adalah bagian terpenting dalam kehidupan manusia. Komunikasi menurut Astrid Susanto adalah: "Komunikasi adalah proses penyampaian pendapat, pikiran dan perasaan seseorang atau sekelompok orang kepada orang lain" Defenisi ini mengungkapkan bahwa didalam komunikasi, penyampaian kata-kata dari komunikator akan menyebabkan terjadinya perubahan tingkah laku seseorang. Jadi pengertian komunikasi dari aspek etimologis seperti yang dikemukakan para ahli tersebut adalah: pemberitahuan, pemberi bagian, pertukaran, berdialog atau bermusyawarah. Kemudian batasan atau defenisi-defenisi tentang komunikasi seperti yang dikemukakan Albig adalah: "Komunikasi adalah proses penyampain pendapat, pemikiran dan perasaan seseorang atau sekelompok orang kepada orang lain.”, Kemudian, pendapat yang dikemukakan Shannon dan Weafer adalah :

"Komunikasi mencakup semua prosedur melalui mana pikiran seseorang dapat mempengaruhi orang lain." Selanjutnya

\section{Jurnal Penelitian Ilmu Manajemen}


menurut Miller : "Komunikasi berarti berlalunya informasi dari satu tempat ke tempat yang lain." Babcok menegaskan bahwa komunikasi adalah sebuah kejadian bias diamati dalam bekerjanya simbolsimbol (art) dalam lingkungan tertentu (scene) oleh individu atau beberapa individu (agent), dengan menggunakan media (agency), untuk mendefinisikan tujuan. Proses saling menukar informasi, gagasan atau ide serta perasaan dengan menggunakan lambing-lambang yang mengandung arti diantara komunikator dan komunikan yang bertujuan untuk membentuk dan merubah sikap seseorang atau kelompok merupakan kesimpulan dari apa yang dimaksud dengan komunikasi tersebut.

\section{Internet}

Internet (Interconnected Network) adalah jaringan-jaringan komputer yang saling terkoneksi satu sama lain. Internet memungkinkan orang-orang atau perusahaan-perusahaan di seluruh dunia untuk saling berkomunikasi suatu sama lain secara efektif dan murah. Sesuai dengan kepanjangannya, internet terdiri dari sekumpula jaringan komputer milik perusahaan, institusi, lembaga pemerintah, ataupun penyedia jasa jaringan (ISP/internet service provider) yang saling terhubung dimana masing masing jaringan komputer yang dikelola secara independen. Pengembangan internet sendiri sebenarnya sudah mulai dirintis sejak tahun 1960-an sebagai proyek dari departemen pertahanan amerika serikat. Internet menjadi salah satu media yang dijadikan sumber informasi paling populer antar mahasiswa perguruan tinggi di dunia. Suatu sumber informasi menurut Murtonen adalah pembawa informasi yang terpercaya dan dapat memberikan kepuasan dalam memenuhi kebutuhan informasi. Penggunaan internet telah menjadi sebuah gaya hidup (life style) bagi sebagaian besar mahasiswa perguruan tinggi di seluruh dunia. Bagi mereka internet adalah sebuah alat fungsional yang telah mengubah cara seseorang berinteraksi dengan orang lain, maupun dalam menemukan informasi. Banyak diantara mahasiswa yang menggunakan internet untuk menyelesaikan berbagai kepentingan akademis, baik itu dilakukan melalui pertukaran e-mail dengan fakultas, teman sebaya, atapun kepentingan lainnya, termasuk melakukan bisnis online, baik itu sebagai penjual, reseller, maupun pembeli. Dengan kata lain seseorang yang memiliki akses internet dapat berkomunikasi langsung

\section{Jurnal Penelitian Ilmu Manajemen}


dengan seseorang yang lain, membuat informasi yang bermanfaat bagi orang lain, menemukan informasi-informasi yang disediakan orang lain atau menjual dan membeli produk-produk tertentu dengan biaya yang minimum dengan jaringan yang terhubung secara global. Dalam perkembangannya, internet mempunyai nilai bisnis antara lain;

a. Menghasilkan pendapatan baru dari penjualan online.

b. Mengurangi biaya transaksi melalui penjualan online dan dukungan pelanggan. c. Menarik pelanggan baru melalui iklan dan pemasaran webserta penjualan on-line.

d. Meningkatkan loyalitas pelanggan saat ini melalui perbaikan dan dukungan.

e. Peningkatan kebutuhan informasi pada masyarakat informasi, khususnya kalangan akademik dan pebisnis dirasakan semakin meningkat akibat adanya saling keterkaitan dan ketergantungan individu terhadap informasi. Diantara banyak kebutuhan manusia, kebutuhan yang paling mencolok peningkatannya adalah kebutuhan akan informasi. Oleh karena itu pemilihan sumber informasi menentukan seseorang terhadap pemenuhan kebutuhannya. Disamping itu, pemilihan sumber informasi seseorang juga didasarkan pada pola kebiasaan. Meyers, Nathan, dan Saxton menyatakan bahwa pola kebiasaan diartikan bila di masa lalu sebuah sumber informasi dapat memenuhi kebutuhan seseorang maka ia akan cenderung menggunakan sumber informasi tersebut untuk waktu selanjutnya. Leckie menambahkan bahwa pengetahuan seseorang tentang sumber informasi (awareness of information sources) yang akan digunakan, seperti kecepatan akses (accessibility), kualitas (quality), ketepatan waktu (timeliness), kepercayaan (trustworthiness), kebiasaan (familiarty) dan keberhasilan sebelumnya (previous success) akan berdampak langsung pada pelaksanaan pencarian informasi (information is sought). Sehingga hal inilah yang mendorong seseorang untuk memilih media yang tepat sebagai sumber informasi bagi pemenuhan kebutuhannya.

\section{Aktivitas Internet}

Horrigan menggolongkan aktivitas aktivitas internet yang dilakukan para pengguna internet menjadi empat kelompok kepentingan penggunaan internet, yaitu :

a. Email ; yaitu aktivitas komunikasi dalam bentuk surat-menyurat dalam bentuk surat elektronik.

\section{Jurnal Penelitian Ilmu Manajemen}


b. Aktivitas kesenangan (fun activities), yaitu aktivitas yang sifatnya untuk kesenangan atau hiburan seperti : online untuk bersenang-senang, klip video atau audio, pesan singkat, mendengarkan atau mendownload musik, bermain game, chatting;

c. Kepentingan informasi (information utility), yaitu aktivitas internet untuk mencari informasi, seperti : informasi produk, informasi travel, cuaca, informasi tentang film, musik, buku, berita, sekolah, kesehatan, pemerintah,keuangan, pekerjaan, dan informasi tentang politik;

d. Transaksi (transaction), yaitu aktivitas transaksi (jual beli) melalui internet seperti : membeli sesuatu, memesan tiket perjalanan, online banking, dan lain lain.

\section{Bisnis Online / E-commerce}

E-commerce adalah kegiatan-kegiatan bisnis yang menyangkut konsumen (consumers), manufaktur (manufactures), service providers dan pedagang perantara (intermediaries), dengan menggunakan jaringan-jaringan komputer (computer networks) yaitu internet. Dengan kata lain e-commerce adalah merupakan suatu transaksi komersial yang dilakukan antara penjual dan pembeli atau dengan pihak lain dalam hubungan perjanjian yang sama untuk mengirimkan sejumlah barang, pelayanan, atau perahlian hak. Dalam pengertian lain, ecommerce adalah pembelian dan penjualan, pemasaran dan pelayanan serta pengiriman dan pembayaran produk, jasa dan informasi di internet dan jaringan lainya, antara perusahaan berjaringan dan pelanggan, pemasok, dan mitra bisnis lainya. Shim mendefinisikan e-commerce (electronic commerse) sebagai konsep baru yang bisa digambarkan sebagai proses jualbeli barang atau jasa pada World Wide Web Internet. Atau menurut Turban e-commerce merupakan jual beli atau pertukaran produk, jasa dan informasi melalui jaringan informasi termasuk internet. Sedangkan menurut Kalakota dan Whinston mendefinisikan e-commerce dari beberapa perspektif berikut:

a. Perspektif komunikasi: e-commerce merupakan pengiriman informasi, produk/ layanan, atau pembayaran melalui lini telepon, jaringan komputer atau sarana elektronik lainnya.

b. Perspektif proses bisnis: e-commerce merupakan aplikasi teknologi

menuju otomisasi transaksi dan aliran kerja perusahaan.

c. Perspektif layanan: e-commerce merupakan salah satu alat yang

\section{Jurnal Penelitian Ilmu Manajemen}


memenuhi keinginan perusahaan, konsumen dan manajemen dalam memangkas service cost ketika meningkatkan mutu barang dan kecepatan pelayanan.

d. Perspektif online: e-commerce berkaitan dengan kapasitas jual beli produk dan informasi di internet dan jasa online lainnya.

Penggunaan e-commerce pada saat ini merupakan syarat bagi sebuah organisasi atau perusahaan, agar perusahaan itu dapat bersaing secara global. Banyak penelitian yang menekankan efisiensi dalam penggunaan e-commerce. Selain itu juga peneliti banyak melihat dampak positif yang diberikan oleh e- commerce dibandingkan dampak negatifnya.1Sekarang banyak perusahaan, baik perusahaan kecil atau perusahan besar memanfaatkan e-commerce sebagai upaya meningkatkan bisnisnya. Berdasarkan penelitian dan studi kasus di Australia, ada beberapa faktor yang mendorong perusahaan dalam memanfaatkan e-commerce:

a. Penggunaan komputer dam teknologi informasi oleh sebuah perusahaan. b. Penerapan e-commerce saat ini, dan rencana dimasa yang akan datang.

c. Kendala dalam penggunaan e-commerce. d. Keahlian dari staff teknologi informasi pada sebuah perusahaan.

Manurut Yau, e-commerce setidaknya memberikan enam buah dampak positif bagi operasi bisnis suatu perusahaan. Keenam dampak tersebut yaitu:

a. meningkatkan efisiensi,

b. penghematan biaya,

c. memperbaiki kontrol terhadap barang,

d. memperbaiki rantai distribusi (supply chain),

e. membantu perusahaan menjaga hubungan yang lebih baik terhadap pelanggan, dan

f. membantu perusahaan dalam menjaga hubungan yang lebih baik terhadap pemasok (supplier).

Menurut Nasution, terdapat beberapa kendala dalam bisnis online:

a. Terbatasnya pengetahuan tentang bisnis online.

Banyak orang yang ikut-ikutan membuka toko online, namun dia tidak mengetahui apa saja yang harus dilakukan untuk menunjang kesuksesan bisnisnya. Sehingga bisnis online yang dijalankan, hasilnya juga tidak optimal.

b. Banyaknya penipuan di dunia maya, membuat kepercayaan konsumen akan bisnis online masih kurang.

\section{Jurnal Penelitian Ilmu Manajemen}


Penipuan yang sering terjadi yaitu uang sudah dibayarkan namun produk tidak dikirimkan, atau kualitas produk tidak sesuai dengan gambar yang ditampilkan.

Dengan demikian konsumen lebih sering kecewa jika mereka membeli produk secara online, dan lebih yakin membeli produk offline karena bisa melihat dan memegang langsung produk yang ingin dibelinya.

c. Persaingan bisnis online yang sangat tinggi.

Kemajuan teknologi informasi dan komunikasi telah mendukung sebagian besar orang memasarkan produknya melalui internet. Dengan demikian dapat dipastikan akan terjadi persaingannya yang sangat ketat, karena peluang bisnis toko online, reseller produk, atau affiliate yang sudah dijalankan ribuan orang di berbagai negara.

d. Kendala koneksi internet.

Bagi pelaku bisnis online yang tinggal di daerah kota, koneksi internet bukan menjadi kendala. Namun bagi orangorang yang tinggal di daerah pinggiran, koneksi internet masih sangat terbatas.

e. Masalah pemasok adalah masalah yang dapat terjadi di awal memulai bisnis online shop, atau dapat saja terjadi di tengah perjalanan bisnis ini.

Masalah umum yang biasa dialami adalah ketika reseller atau pebisnis online shop kesulitan menemukan partner pemasok barang yang tepat sehingga kegiatan penjualan terhambat karena barangnya tidak tersedia. Atau dapat saja yang terjadi adalah ketika reseller dan atau supplier memiliki masalah yang akhirnya menyebabkan supplier tidak melanjutkan kerjasama untuk menyalurkan barang. Sebagai pebisnis, tentunya hal ini harus dapat dihindari.

E-commerce dibedakan menjadi beberapa jenis berdasarkan karakteristiknya yaitu:

a. Business To Business (B2B)

Business To Business memiliki karakteristik:

1) Trading partners yang sudah saling mengetahui dan antara mereka sudah terjalin hubungan yang berlangsung cukup lama. Informasi yang dimiliki hanya ditukar dengan partner tersebut.

2) Pertukaran data dilakukan secara berulang-ulang dan berkala dengan format data yang telah disepakati bersama. 
3) Salah satu pelaku tidak harus menunggu rekan mereka lainnya untuk mengirimkan data.

4) Model yang umum digunakan adalah peer to peer, di mana processing intelligence dapat didistribusikan di kedua pelaku bisnis.

b. Business To Consumer (B2C)

Business To Consumer memiliki karakteristik :

1) Terbuka untuk umum, di mana informasi disebarkan secra umum pula dan dapat diakses secara bebas.

2) Servis yang digunakan bersifat umum, sehingga dapat digunakan oleh orang banyak. Sebagai contoh, karena sistem web sudah umum digunakan maka service diberikan dengan berbasis web.

3) Servis yang digunakan berdasarkan permintaan. Produsen harus siap memberikan respon sesuai dengan permintaan konsumen.

4) Sering dilakukan sistem pendekatan client-server.

c. Consumer to Consumer (C2C)

Dalam C2C seorang konsumen dapat menjual secara langsung barangnya kepada konsumen lainnya, atau bisa disebut juga orang yang menjual produk dan jasa ke satu sama lain. Contohnya adalah ketika ada perorangan yang melakukan penjualan di classified ads (misalnya, www.classified2000.com) dan menjual properti rumah hunian, mobil, dan sebagainya. Mengiklankan jasa pribadi di internet serta menjual pengetahuan dan keahlian merupakan contoh lain C2C. sejumlah situs pelelangan memungkinkan perorangan untuk memasukkan item-item agar disertakan dalam pelelangan. Akhirnya, banyak perseorangan yang menggunakan intranet dan jaringan organisasi untuk mengiklankan itemitem yang akan dijual atau juga menawarkan aneka jasa. Contoh lain yang terkenal adalah eBay.com, yaitu perusahaan lelang.

d. Customer to Business (B2C)

Customer to Business adalah model bisnis dimana konsumen (individu) menciptakan nilai, dan perusahaan mengkonsumsi nilai ini. Sebagai contoh, ketika konsumen menulis review, atau ketika konsumen memberikan ide yang berguna untuk pengembangan produk baru, maka individu ini adalah yang menciptakan nilai bagi perusahaan, jika perusahaan 
tersebut mengadopsi input nya. Sebagai contoh, Priceline.com merupakan situs yang memungkinkan seseorang menjual barang kepada perusahaan. Dalam hal ini, internet dapat digunakan sebagai sarana negosiasi. Penggunaan ecommerce merupakan sebuah keharusan dalam dunia usaha, mengingat masalah yang semakin kompleks, kompetitor yang semakin menjamur dan tuntutan untuk selalu mengikuti perkembangan dunia global yang mengharuskan untuk selalu bertindak kreatif. Diharapkan dengan pemanfaatan e- commerce ini memberikan dampak pada akselerasi perkembangan dunia usaha baik usaha skala kecil, menengah maupun kelas atas. Dampak positif ini tentu akan dirasakan apabila perusahaan dapat menggunkan e-commerce dengan tepat dan disesuaikan dengan jenis dan karakter usahanya. Salah satu fungsi dari pemanfaatan e-commerce ini adalah adanya efisiensi terhadap dunia usaha. Baik efisien secara materil (biaya) maupun secara non-materil (tenaga dan waktu). Dari segi biaya, perusahaan dapat menekan biaya misalnya dengan memanfaatkan telepon dan internet sebagai media penawaran dan promosi barang atau jasa. Karena hal tersebut akan lebih murah dibandingkan dengan cara tradisional atau ofiline. Di sisi lain, efisiensi biaya ini juga bisa terjadi karena adanya pengurangan tenaga kerja pada posisi tertentu. Selain itu, penggunaan e-commerce juga dapat menekan waktu kerja. Hal ini terjadi misalnya dengan pemanfaatan fax dan email dalam mengirimkan berbagai surat bisnis. Dengan demikian, pemanfaatan e-commerce selain berimplikasi pada peningkatan pelayanan terhadap pelanggan (konsumen/nasabah) atau klien, juga dapat dimanfaatkan sebagai alat strategi dalam menghadapi kompetitor atau pesaing. Dalam hubungannya terhadap pelayanan kosumen, e-commerce akan mempermudah komunikasi dan transaksi antara penjual dan pembeli. Perkembangan teknologi informasi akibat dari hasil globalisasi juga akan melahirkan apa yang diaggap sebagai "pesaing" atau "competitor" yang sangat tajam dalam dunia bisnis. Globalisasi ekonomi membentuk perubahan menjadi radikal, serentak, dan pervasif ke dalam berbagai aspek. Perusahaan harus memiliki kemampuan 
untuk merespons dengan cepat untuk beradaptasi terhadap perubahan yang terjadi sehingga perusahaan mampu dalam menghadapi persaingan yang begitu ketat.

Peranan e-commerce diharapkan mampu memberikan manfaat yang signifikan dalam menghadapi dunia bisnis yang penuh persaingan tersebut. Perusahaan yang survive dan konsisten serta cenderung meningkat adalah perusahaan yang mampu menerjemahkan dunia teknologi ke dalam dunia usahanya. Penggunaan ecommerce adalah salah satu bentuk implementasi perkembangan teknologi untuk memasarkan produknya (barang atau jasa) ke segala tempat dan yang besar-besaran. Promosi besar-besaran dengan harapan banyak mendatangkan pengunjung ternyata tidak selamanya menguntungkan.8

\section{Teori Uses and Gratifications}

Asal mula terciptanya Teori Uses and Gratifications yaitu beberapa peneliti meneliti kebutuhan manusia secara psikologis dan sosial, penelitian ini meneliti bagaimana faktor-faktor sosial dan psikologis, termasuk kebutuhan untuk aktivasi, berinteraksi untuk menghasilkan gaya hidup dan pola penggunaan media yang berbeda. Penelitian ini mengidentifikasi empat jenis gaya hidup yang anggotanya berbeda secara signifikan pada berbagai variabel, termasuk surat kabar dan majalah berita pembaca, dan gratifikasi dicari dari televisi kabel. Orang dengan kebutuhan tinggi untuk aktivasi memiliki gaya hidup yang melibatkan paparan yang lebih besar untuk sumber-sumber media informasi urusan publik dibandingkan dengan kebutuhan yang lebih rendah untuk aktivasi dan gaya hidup yang kurang kosmopolitan. Hasilnya menunjukkan bahwa akar dari penggunaan media yang jauh lebih dalam dari yang diyakini sebelumnya. Teori Uses and Gratifications memusatkan perhatian pada kegunaan isi media untuk memperoleh gratifikasi atau pemenuhan kebutuhan. Pengguna aktif menurut penjelasan dari Blumer Active Audience yaitu:

1. Utilitas: media memiliki keuntungan bagi orang-orang dan orang-orang dapat menempatkan dan menggunakan media tersebut.

2. Intensionalitas: motivasi sebelum orang menentukan konsumsi konten media.

3. Selektivitas: pemilihan media hanya digunakan untuk kepentingan sendiri.

\section{Jurnal Penelitian Ilmu Manajemen}


4. Imperviousness Mempengaruhi penonton membangun makna mereka sendiri dari konten yang bias mempengaruhi apa yang mereka pikirkan dan lakukan. Mereka dapat menghindari beberapa jenis pengaruh media yang negatif.

Katz, Blumer, and Gruvitch menguraikan lima elemen atau asumsi asumsi dasar dari uses and gratification media sebagai berikut

1. Audiens dipandang bersikap aktif, artinya peranan penting manfaat media diasumsikan berorientasi pada sasaran.

2. Dalam proses komunikasi massa, banyak inisiatif pengaitan antara gratifikasi kebutuhan dan pilihan media yang terletak pada audien.

3. Media bersaing dengan sumber-sumber pemenuhan kebutuhan yang lain untuk memuaskan kebutuhannya. Kebutuhan yang dipenuhi media hanyalah bagian dari rentangan kebutuhan manusia yang lebih luas. Bagaimana kebutuhan ini terpenuhi melalui konsumsi media amat bergantung kepada perilaku khalayak yang bersangkutan.

4. Banyak tujuan pemilih media massa disimpulkan dari data yang diberikan khalayak; artinya,orang dianggap cukup mengerti untuk melaporkan kepentingan dan motif pada situasi-situasi tertentu.

5. Penilaian tentang arti kultural dari media massa harus ditangguhkan sebelum diteliti lebih dahulu orientasi khalayak.

Kebutuhan dan motif penggunaan media atau Uses and Gratifications dimulai di lingkungan sosial, dimana yang dilihat adalah kebutuhan-kebutuhan khalayak. Lingkungan sosial meliputi ciri-ciri afialiasi kelompok dan ciri-ciri kepribadian. Kebutuhan individual dikategorisasikan, sebagai berikut :

1. Kebutuhan Kognitif (Cognitif Needs)

Kebutuhan yang berkaitan dengan peneguhan informasi, pengetahuan dan pemahaman mengenai lingkungan. Kebutuhan ini didasarkan pada hasrat untuk memahami dan menguasai lingkungan, juga memuaskan rasa penasaran dan dorongan untuk penyelidikan.

2. Kebutuhan Afektif (Affective Needs)

Kebutuhan yang berkaitan dengan peneguhan pengalaman-pengalaman yang estetis, menyenangkan dan emosional.

3. Kebutuhan Pribadi (Personal Integrative Needs) 
Yaitu kebutuhan yang berkaitan dengan kredibilitas, kepercayaan, stabilitas, dan status individual. Hal tersebut diperoleh dari hasrat akan harga diri.

4. Kebutuhan Sosial Secara Integratif (Social Integrative Needs)

Kebutuhan yang berkaitan dengan peneguhan kontak dengan keluarga, teman dan dunia. Hal hal tersebut didasarkan pada hasrat berafiliasi.

5. Kebutuhan Pelepasan (Escapist Needs) Kebutuhan yang berkaitan dengan upaya menghindarkan tekanan, ketegangan, dan hasrat akan keanekaragaman.

Beraneka ragamnya kebutuhan tersebut menimbulkan motif motif tertentu dalam diri seseorang untuk menentukan tindakannya, khususnya dalam motif penggunaan media. Motif jika dihubungkan dengan konsumsi media berarti segala alasan dan pendorong dalam diri seseorang menyebabkan orang tersebut menggunakan media dan tujuannya dalam menggunakan media tersebut. Disamping itu, seleksi terhadap media yang dilakukan oleh audiens disesuaikan dengan kebutuhan dan motif. Seleksi media ini berlaku untuk semua jenis media baik media cetak atau elektronik. Keinginan dan kebutuhan masing masing individu berbeda dari waktu ke waktu dan dari tempat ke tempat, sehingga motif yang dimiliki berbeda beda.

Mc Quail, Blumler, dan Brown mengusulkan empat kategori motif penggunaan media berdasarkan penelitian mereka di Inggris, antara lain :

1. Pengalihan (diversion), pelarian dan rutinitas dan masalah ; pelepasan emosi.

2. Hubungan sosial (social relationship), manfaat sosial informasi dalam percakapan ; pengganti media untuk kepentingan perkawanan.

3. Identitas pribadi atau psikologi individu (personal identity and individual psychology), penguatan nilai atau penambah keyakinan; pemahaman diri ; eksplorasi realitas ; dan sebagainya.

4. Pengawasan (surveillence), informasi mengenai hal hal yang mungkin mempengaruhi seseorang atau akan membantu seseorang melakukan atau menuntaskan sesuatu.

Effendy mengatakan bahwa teori Uses and Gratifications dimulai dari lingkungan sosial, dimana yang dilihat adalah kebutuhan khalayak. Lingkungan sosial meliputi ciri ciri afiliasi kelompok dan ciri ciri kepribadian. Sehingga, berangkat dari lingkungan sosial inilah individu menentukan kebutuhannya dengan

\section{Jurnal Penelitian Ilmu Manajemen}


menggunakan beragam pilihan non media maupun media sebagai alat pemenuhan kebutuhan. Kemudian, pada aspek kebutuhan akan media inilah yang menghasilkan media gratifications, yakni berupa pengawasan, hiburan, identitas diri dan hubungan sosial. Teori uses and gratification banyak digunakan sebagai acuan oleh para peneliti didunia untuk mengetahui motif motif penggunaan internet yang dilakukan individu yang berasal dari berbagai kalangan. Dalam hal ini, internet merupakan media yang saat ini sedang digemari oleh banyak kalangan, dengan beragam motif penggunaan yang berbeda beda. Berdasarkan survey yang dilakukan Charney pada tahun 1996 menunjukkan bahwa komunikasi, interaksi, dan informasi sebagai tiga kategori besar mengapa seseorang menggunakan internet dalam pemenuhan kebutuhan informasinya. Kemudian studi yang dilakukan Kaye pada tahun 1998 mengusulkan enam kategori motif seseorang berinteraksi atau menggunakan www (web) atau internet, antara lain :

1. Hiburan,

2. Interaksi,

3. Menghabiskan waktu,

4. Melarikan diri dari kepenatan,
5. Informasi,

6. Preferensi penggunaan situs web.

Penelitian yang dilakukan oleh Valkenberg dan Soeters pada tahun 2001 menunjukan bahwa karakteristik demografi mempengaruhi perilaku seseorang dalam menggunakan internet. Disamping itu, Sherman pada tahunn 2000 menyelidiki kesenjangan gender pada pengguna internet antara mahasiswa dengan membandingkan pola penggunaan dan sikap terhadap internet. Hasil studi menunjukkan bahwa terdapat perbedaan pola penggunaan dan sikap antara pengguna laki laki dan perempuan. Secara umum, perbedaan pola tersebut terletak pada cara dan pengalaman mereka dalam menggunakan teknologi internet. Selain karakteristik demografis, pengetahuan dan keterampilan atau skill juga berpengaruh dalam penggunaan media berupa internet. Hargittai mengungkapkan bahwa salah satu prediksi yang kuat untuk mengetahui pengetahuan dan keterampilan (skill) seseorang berinteraksi menggunakan internet adalah pengalaman berinternet seseorang. Menurutnya lamanya seseorang (dalam tahun) menggunakan internet bisa berfungsi sebagai wakil dari keterampilan melek digital (digital literacy skill). Kemudian Palmquist dan Kim mengatakan

\section{Jurnal Penelitian Ilmu Manajemen}


bahwa pengalaman didefinisikan sebagai lebih dari 2 tahun berpengalaman menelusur secara online dan ini berkaitan dengan penggunaan online database. Variasi dalam perilaku berinternet juga ditentukan oleh tingkat pengalaman dalam menggunakan internet.

Dengan demikian, landasan utama pendekatan studi Uses and Gratification jika dikaitkan dengan penggunaan media internet sebagai media untuk menelusur informasi adalah sebagai berikut:

1. Penggunaan media pada akhirnya untuk mencapai suatu tujuan tertentu, dimana individu menggunakan suatu media (internet) untuk memenuhi kebutuhankebutuhan yang bersifat spesifik dan kebutuhan tersebut berkembang didalam lingkungannya;

2. Individu memilih sendiri jenis serta isi didalam media (internet) guna memenuhi kebutuhan akan informasi yang di inginkan. Dengan demikian individu tersebut akan terlibat dalam suatu proses penelusuran informasi menggunakan media yang digunakannya (internet) untuk mendapatkan kebutuhan akan informasi yang di harapkan.

Manusia menggunakan teori Uses and Gratifications dapat dilihat pada kasus-kasus seperti pemilihan musik pribadi. Manusia memilih musik tidak hanya untuk menyesuaikan suasana hati tertentu, tetapi juga dalam upaya untuk menunjukkan pemberdayaan atau motif hati nurani sosial lainnya.

\section{METODOLOGI PENELITIAN}

Penelitian ini merupakan penelitian kualitatif yang bertujuan mengetahui hambatan-hambatan dalam bisnis online serta solusi yang sering dilakukan oleh para pelaku bisnis online, baik sebagai pembeli maupun penjual.

Sumber Data

Sumber data dalam penelitian ini dipilih dengan menggunakan metode purposive sampling, yakni responden diambil dari kalangan pelaku usah yang ada di desa buden yang sering melakukan transaksi dalam bisnis online, baik sebagai pembeli maupun penjual. Adapun yang menjadi responden dalam penelitian ini adalah :

Penjual bisnis online:

a. Subjek 1. Bpk. Ichsan. 54 tahun. Pelaku usaha penjualan bibit ikan di Ds. Buden.

b. Subjek 2. Ali. 49 tahun. Pelaku usaha penjualan bibit ikan di Ds. Buden.

Sebagai penjual online yang memasarkan bibit ikan.

Pembeli bisnis online:

\section{Jurnal Penelitian Ilmu Manajemen}


a. Subjek \#3. Imam Rosyadi. 36 tahun. Sebagai konsumen bisnis online yang sering membeli bibit ikan.

b. Subjek \#4. Sujono. 43 tahun.

Sebagai konsumen bisnis online yang sering membel bibit ikan.

c. Subjek \#5. Jejen Andre T. 24 tahun.

Sebagai konsumen bisnis online yang sering membeli bibit ikan.Wawancara subjek penelitian dilakukan pada tempat dan waktu yang terpisah.

Wawancara dengan Subjek \#1 dan Subjek \#2 dilakukan di kediaman subjek, pada tanggal 19 Oktober 2018, dimulai pada pukul 09.00. Wawancara dengan Subjek \#3 dan \#4 dilakukan di café Giri Hills Gresik pada tanggal 19 Oktober 2018, dimulai pada pukul 17.45. Wawancara dengan Subjek \#5 dilakukan di café Giri Hills pada tanggal 19 Oktober 2018, dimulai pada pukul 21.35.

\section{Teknik Pengumpulan Data}

Pada penelitian ini pengumpulan data dilakukan dengan menggunakan metode metode wawancara terstruktur dan observasi. Alasan dipilihnya metode wawancara terstruktur dalam penelitian ini adalah karena didalam penelitian ini, informasi yang diperlukan adalah berupa kata-kata yang diungkapkan subjek secara langsung, sehingga dapat dengan jelas menggambarkan pengalaman subjek penelitian dalam bisnis online dan mewakili kebutuhan informasi dalam penelitian. Observasi adalah pengamatan dan pencatatan secara sistematik terhadap gejala yang tampak pada objek penelitian.

\section{Teknik Analisis Data}

Setelah data diperoleh dari studi pustaka dan riset lapangan dikumpulkan dan diklasifikasikan, maka langkah selanjutnya dalam penelitian ini adalah melakukan analisis data. Analisis data adalah suatu cara atau langkah untuk mengolah data primer maupun data skunder yang bermanfaat bagi penelitian guna mencapai tujuan akhir penelitian.

Anonymous (2009). Dalam metode kualitatif, instrumen pengumpulan data yang digunakan antara lain wawancara mendalam dengan individu, wawancara terstruktur dan nonstruktur, kelompok fokus, narasi, analisis konten atau dokumenter, observasi partisipan, dan penelitian arsip.

Menurut Prof.Dr. Suharsimi Arikunto (2010) menyatakan bahwa proses analisis data terdiri dari 3 yaitu:

1. Persiapan

2. Tabulasi

\section{Jurnal Penelitian Ilmu Manajemen}


3. Penerapan data sesuai dengan pendekatan penelitian

a. Persiapan

Kegiatan dalam langkah persiapan ini antara lain :

1) Mengecek nama dan kelengkapan identitas pengisi. Apalagi instrumennya anonim,perlu sekali di cek sejauh mana atau identitas apa saja yang sangat di perlukan bagi pengelolahan data lebih lanjut.

2) Mengecek kelengkapan data, artinya memeriksa isi instrumen pengumpulan data (termasuk pula kelengkapan lembaran instrumen barangkalai ada yang terlepas atau sobek).

3) Mengecek macam isian data.

b. Tabulasi

G.E.R. Burroughas mengemukakan klasifikasi analisis data sebagai berikut :

1) Tabulasi data (the tabulation of the data).

2) Penyimpulan data (the summarizing of the data).

3) Analisis data untuk tujuan testing hipotesis.

4) Analisis data untuk tujuan penarikan kesimpulan. c. Penerapan data sesuai dengan pendekatan penelitian

Pengelolahan data yang di peroleh dengan menggunakan rumus-rumus atau aturan-aturan yang ada,sesuai dengan pendekatan penelitian atau desain yang di ambil.

\section{PEMBAHASAN HASIL PENELITIAN}

Dari hasil wawancara yang dilakukan terhadap kelima responden, didapat beberapa hambatan-hambatan dan solusi dalam bisnis online sebagai berikut:

a. Masalah keterlambatan pengiriman dari supplyer.

\section{Solusi :}

Subjek \#1 secara jujur menyatakan estimasi waktu pengiriman serta kemungkinan keterlambatan pengiriman.

Hal ini juga dapat menjadi penyebab keterlambatan pengiriman seperti hambatan yang dialami subjek \#3. Dimana keterlambatan pengiriman dari supplyer, dapat memperpanjang waktu pengiriman dari penjual kepada pembeli.

b. Masalah barang tidak sesuai ekspektasi pembeli.

Solusi: Subjek \#1 bernegosiasi dengan konsumen untuk mencapai resolusi, yaitu mengembalikan uang konsumen dan barang yang dibeli (membatalkan transaksi). Subjek 
\#2 sebisa mungkin berusaha menampilkan foto promosi yang realistis. Subjek \#4 menyarankan untuk lebih mempercayai foto promosi yang menggunakan foto ikan, pengiriman dan pengemasan, karena lebih realistis. Dari sini dapat disimpulkan bahwa foto promosi suatu produk, khususnya bibit ikan, lebih baik untuk menggunakan model sebagai foto promosi, karena lebih realistis dibandingkan foto promosi yang tidak menggunakan foto ikan nya.

c. Masalah pengiriman tidak sesuai dengan alamat pembeli.

Solusi: Subjek \#2 menyatakan kalau pembeli bisnis online harus memberikan alamat yang jelas dan tepat.

Dari sini didapatkan bahwa jika seseorang ingin membeli suatu barang secara online, hendaknya ia mempelajari alamat lengkap tujuan pengiriman terlebih dahulu, untuk menghindari kesalahan pengiriman oleh pembeli.

d. Masalah penipuan/barang tidak dikirim.

Solusi: Subjek \#5 menyarankan untuk mempelajari kinerja penjual online melalui respon-respon pelanggan yang biasanya tertera di halaman promosi penjual online.

Ini juga dapat digunakan oleh penjual bisnis online, untuk menyediakan tempat bagi para pembeli untuk memberi respon yang dapat dibaca secara umum. Karena dengan responrespon pembeli yang baik, dapat meningkatkan reputasi penjual online hingga lebih terpercaya.

\section{KESIMPULAN}

Dari hasil wawancara yang dilakukan terhadap kelima responden, didapat beberapa hambatan-hambatan dan solusi dalam bisnis online sebagai berikut:

1. Masalah keterlambatan pengiriman dari supplyer.

Solusi :

Pembeli menyatakan estimasi waktu pengiriman serta kemungkinan keterlambatan pengiriman.

2. Masalah barang tidak sesuai ekspektasi pembeli.

Solusi: Foto promosi suatu produk, khususnya produk busana, lebih baik untuk menggunakan model sebagai foto promosi, karena lebih realistis dibandingkan foto promosi yang tidak menggunakan foto ikan.

3. Masalah pengiriman tidak sesuai dengan alamat pembeli.

Solusi: Jika seseorang ingin membeli suatu barang secara online, hendaknya ia mempelajari alamat lengkap tujuan pengiriman terlebih dahulu, untuk menghindari kesalahan pengiriman oleh pembeli.

\section{Jurnal Penelitian Ilmu Manajemen}


4. Masalah penipuan/barang tidak dikirim.

Solusi: Mempelajari kinerja penjual online melalui respon-respon pelanggan yang biasanya tertera di halaman promosi penjual online. Ini juga dapat digunakan oleh penjual bisnis online, untuk menyediakan tempat bagi para pembeli untuk memberi respon yang dapat dibaca secara umum. Karena dengan respon-respon pembeli yang baik, dapat meningkatkan reputasi penjual online hingga lebih terpercaya.

\section{Saran}

1. Institusi

Penelitian ini masih perlu dilakukan pengembangan, oleh karena itu untuk penelitian mendatang terhadap e-commerce perlu dikaji lebih lanjut mengenai analisis hambatan bisnis online.

2. Masyarakat, Khususnya Pelaku Usaha Penjualan Ikan

Dapat mengkaji hasil penelitian ini sebagai pembelajaran sebelum melakukan bisnis online, baik itu sebagai penjual, reseller, maupun pembeli.

\section{DAFTAR PUSTAKA}

Candra Ahmadi dan Dadang Hermawan. 2013. E-Business \& E-Commerce, Penerbit Andi, Yogyakarta.
Suprapto P. 2009. Pengantar Teori dan Manajemen Komunikasi. Buku Kita. Jakarta. Indonesia..

Somad R, Priansa D.J. 2014. Manajemen Komunikasi: Mengembangkan Bisnis Berorientasi Pelanggan. Penerbit Alfabeta. Bandung. Indonesia.

Kartajaya, Syakir Sula. 2006. Syariah Marketing. Penerbit PT Mizan Pustaka, Bandung.

West R, Turner L.H. 2008 Pengantar Telekomunikasi. Edisi 3. Buku 1. Salemba Humanika. Jakarta. Indonesia..

Daryanto, Rahardjo M. 2015 Teori Komunikasi. Gava Media. Indonesia. Yogyakarta.

Purwanto D. 2006. Komunikasi Bisnis. Edisi Ketiga. Erlangga. Jakarta. Indonesia.

Sugiono. 2006. Metode Penelitian Kuantitatif Kualitatif, Penerbit Alfabeta, Bandung.

Pawito. Penelitian Komunikasi Kualitatif. LkiS. Yogyakarta. Indonesia. 2008. Tersedia pada

URLhttps://books.google.co.id/books? id=UfM33NzcHJsC. Akses 18 Mei 2017.

https://books.google.co.id/books/id=BBWu CwAAQBAJ. Akses 18 Mei 2017.

Resi P.O., Berto W.M., L. Titah. Identifikasi Permasalahan Komplain pada Ecommerce Menggunakan Metode Fishbone. Jurnal Sains dan Seni ITS. 2017. Vol. 6:1. Hal 37-41 